\section{Revista de la \\ Universidad del Thulia}

Fundada en 1947 por el Dr. Jesúns Enrique Lossada

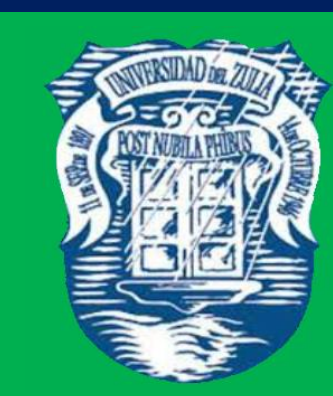

Ciencias del

Algreo

Ingemieria

y Teemología

\section{Aกัต 11 No 29}

Enero - Abril 2021

Tercera Época

Maracaibo-Venezuela 


\title{
Assessment of the main reasons for the stagnation of territorial development in Russia
}

\author{
Anzor V. Misakov * \\ Anzor Kh. Sabanchiev * \\ Lola D. Sanginova ** \\ Elena N. Danilevskaya*** \\ Musa A. Eskiev****
}

ABSTRACT

Globalization, accompanied by a continuous increase in competition, complicates the conditions for the development of market relations in the Russian Federation. The priority development territories should have functioned as a tool for industrial and productive reform. These territories and their special economic zones should have become territorial centers of innovative and industrial development. However, it does not happened. The article analyzes some of the main reasons for this situation in Russia.

KEY WORDS: Special economic zones, priority development territories, strategic management model.

\section{Evaluación de los principales motivos de estancamiento del desarrollo territorial en Rusia}

RESUMEN

La globalización, acompañada de un aumento continuo de la competencia, complica las condiciones para el desarrollo de las relaciones de mercado en la Federación de Rusia. Los territorios de desarrollo prioritario debieron funcionar como una herramienta de reforma industrial y productiva. Dichos territorios y sus zonas económicas especiales, debieron convertirese en focos territoriales de desarrollo innovador e industrial. Sin embargo, esto no sucedió. El artículo analiza algunas de las principales razones de esta situación en Rusia.

PALABRAS CLAVE: Zonas económicas especiales, territorios de desarrollo prioritario, modelo de gestión estratégica.

*PhD in Economics, Researcher at Federal State Budgetary Institution of Science, Russian Academy of Sciences "Kabardino-Balkarian Scientific Center", mvanzor2014@gmail.com

${ }^{* *} \mathrm{PhD}$ in Economics, Associate Professor of the Financial University under the Government of the Russian Federation.

***Senior lecturer at the Krasnodar branch of the Russian Economic University named after G.V. Plekhanov.

${ }^{* * * *}$ Lecturer at FSBEI HE "Chechen State University.

Recibido: 22/01/2020

Aceptado: 28/02/2020 


\section{Introduction}

In September 2016, the Government of the Russian Federation terminated ahead the operation of eight Russian special economic zones (SEZs), due to the absence of any specific work for the previous three years. We have to admit that the TAD and the SEZ have not become yet national innovation and economic spaces, the areas of consciously organized entrepreneurship built on the production of competitive hightech products.

During the activities of special economic zones, the territories of priority development and diverse clusters in the Russian Federation, it became clear that there is no systematization of the structure key elements for the methodological support of strategic management in these entities, there is no model for strategic management of new economic zone development, which would make it possible to create an effective mechanism for interaction between management companies of the ECO with regional authorities of the Russian Federation constituent entities, with numerous residents, investors, and also with the business community.

A special economic zone has a special legal status; the territory of such a zone is subject to preferential economic conditions for the implementation of innovative industrial and other activities.

Enterprises operating in special economic zones are called the residents of the SEZ.

When they create the SEZ in the Russian Federation, the state assumed many complex obligations, including the attraction of private (both domestic and foreign) capital in breakthrough technologies, infrastructure, the development of conditions for job creation, especially for qualified personnel (which helps to keep the intellectual potential in the country), the stimulation of the state import substitution policy implementation.

\section{Research Methodology}

The theoretical and methodological basis of the article was the fundamental and applied works of Russian and foreign scientists in the field of strategic management of the SEZ, economic growth, etc. 
Reasonable conclusions and results of this study were obtained based on the application of general scientific methods of management and the organization of the economic territorial complex, the methods of expert assessments, the methods of organizational and structural modeling and comparative analysis.

\section{Research Results}

The basis for the creation of territorial innovation systems is the idea of building up competitive advantages, which characterizes their purpose as the "locomotive" for the development of the regional economic system.

The activities of such systems, for example, in the United States, are controlled by the interagency Council. The EU has developed a set of legislative standards that provide for the regulation of special economic zone activities. In the Asia-Pacific countries they are guided by the legislative acts of the parliaments from the corresponding Chinese provinces.

Moreover, while private capital of the country acts as the main financial resource in the USA, they are focused mainly on engaging non-state structures in the management process within the EU.

In this regard, Asia-Pacific countries are more focused on customs and tax incentive provision for foreign investors.

This fact is also interesting - the basis for the development of SEZs in the USA is the particularities and needs of the state, and in Europe, this is the need to stimulate entrepreneurial activity, and the development of a flexible investment regime and in China (Baklanov, 2014; Myakisheva, 2015).

For comparison, in Russia - for example, in the North Caucasus Federal District, in particular, in the Kabardino-Balkarian Republic, the basis for the opening of the SEZ was the depressed state of the regional economy. So, there was no social infrastructure in the republic corresponding to modern standards.

The production and transport infrastructure were almost in the same situation, the unemployment rate in the mountainous regions of the republic exceeded $70 \%$, an extremely low level of wages, insufficient quality or the absence of a number of socially 
significant services (Aloeva \& Misakov, 2013; Afashagova et al., 2014; Kushbokova et al., 2009). All this led to the depopulation of the republic.

To eliminate all these negative factors and bring the depressed republic out of this state, it was planned to create conditions for accelerated balanced development in the republic.

Unfortunately, although the SEZ was opened in the Kabardino-Balkarian Republic, nothing came of it - not a single new job was created, it was not possible to attract foreign and also Russian investors, and the climate of investment attractiveness was not developed. Under these conditions, one can't think foreign technologies, expert attraction, etc.

To be fair, we must mention the events of 2005, when an armed attack was carried out on Nalchik by militants on October 13. There were more than 300 militants, which fundamentally undermined investor confidence in the republic.

Besides, the republic had a rather strong bureaucratic mechanism, which made a serious problem, for example, for opening a business or an enterprise connection to gas, electricity, water, etc. All this led to the collapse of the SEZ in the region.

In the Kabardino-Balkarian Republic and other similar regions where the SEZ did not take place, the leadership of these territories could not (or did not want) to understand that the SEZ must be positioned as possible growth points for economic stability in a separate geographical point, which allows the development of an economic framework at the macroregion level. It is appropriate to recall that F. Perroux during the substantiation of "growth poles" theory came to the conclusion that there is a dominant unit within which the processes of nature change and competition maintaining take place. Indeed, the basis of competition is not only the motivation to maintain the maximum individual profit for an organization, but also the maximum profit for the macro unit as a whole (Perroux, 1968).

The dominant macrounit can be considered as a "growth pole", creating an effect for agglomeration, when complementary activities are combined into a single whole (Under the "pole of growth" we consider an enterprise, and an industry, and the totality of industries). It has the ability to create a powerful effect of "enthusiasm" for itself, and 
then transform into the zones of sustainable development and the axis of sustainable development in the macroregion.

In accordance with the provisions by F. Perroux, the key task of state economic policy is the creation of such "growth poles" and the conscious management of the achieved effect distribution environment (Perroux, 1968).

$\mathrm{H}$. Bos argued that the mobilization of a group of business entities in a kind of localized centers is the best option for placement with significant transport costs for the transportation of specialized industry products (Bos, 1970).

As can be seen from the foregoing, the preconditions for a long-term cooperative cluster tie development are formed through localization, which helps to reduce transaction and transportation costs.

However, in order to analyze and diagnose the potential impact of the SEZ on the socio-ecological and economic environment of the region, it is necessary to consider a complete set of spatial and production factors, which will allow us to give a reasonable forecast of the regional economy growth efficiency (Bos, 1970; Enright, 1993).

Creating the economic framework of the macro-region, SEZs are forced to enter into economic ties with other localized points (business entities) in related industries, which inevitably contributes to the development of cooperative value-added chains. Moreover, such economic frameworks can later be transformed into territorial or crossborder clusters (Krutikov, 2017).

It is also appropriate to recall M. Enright, who substantiated that competitive advantages are formed exclusively at the regional level, and not at the national or even international level in the theory of regional economic cluster development (Perroux, 1968).

The analysis of special literature allows us to argue that it is unacceptable to create a SEZ from scratch. Apparently, for this reason, the green-field principle, which is popular in international practice, is not used in the Russian Federation. The consequence of this situation is that when you choose the definition of SEZ, all work was reduced to the struggle of individual constituent entities of the Russian Federation, municipalities and for "their" interests, while the interests of the state were discarded. 
In our opinion, this is natural, because the state strategy for the SEZ creation and development was not a systemic, but "mosaic". During its development, they ignored certain aspects of strategic management fundamental foundations.

As can be seen from the foregoing, special economic zones and territories were not able to act as its drivers in the national economy, as was expected at the time of their creation.

And this is a natural (albeit negative) result, because contrary to the ideology of their development, special economic zones, instead of establishing "special" products competitive in international markets, mainly began to produce typical products, which, incidentally, are produced in neighboring regions or even in the same city. This led to the fact that the SEZ, in fact, performed unfair competition with other Russian producers, producing the same products and working according to general rules. It seems to us that businessmen did not realize (or do not want to realize) that it is unacceptable to place all emphasis in their work only on the preferences received "from above" in the form of tax cuts in comparison with average Russian entrepreneurs.

According to the Accounts Chamber of the Russian Federation, more than 80\% of the products created in the SEZ go exclusively to the domestic Russian market, although it was supposed to be exported as planned (Grinevich, 2019).

International experience of the SEZ shows that this approach discredits the very idea of creating a SEZ and is doomed to failure.

During the audit by the Accounts Chamber of the Russian Federation they found out that 566 residents were registered in all SEZs of the Russian Federation, moreover, more than 350 residents (53\%) were placed in four SEZs. However, only 25\% (76 residents) are covered by foreign economic activity.

Over the years of SEZ activity, the agreements were terminated and 166 residents were liquidated as inappropriate to their functional purpose.

What is characteristic is that any SEZ is a priori designed for the sustainable development of high-tech sectors of the national economy and for the development of the latest products.

However, judging by the audit results of the Accounts Chamber of the Russian Federation, the industrial products imported into Russia by the residents of special 
economic zones, in general, were intended for more ordinary purposes - for the production of standard products, in particular, tires, building materials, etc., which is extremely contrary to their main tasks. Apparently, for this reason, the creation of one workplace in the SEZ had the treasury cost of 10 million rubles (Grinevich, 2019).

It can be clearly stated that the residents of the SEZ are focused not so much on the socio-economic development of the territory as on their own tax minimization. The residents tried to justify such serious omissions, for example, by the fact that projects actually began to be funded only the year after their opening (SEZ "Ulyanovsk"), etc.

To be fair, it should be noted that among the residents of the SEZ there are mainly the enterprises that produce high-tech products or the products of a high degree of processing - they have increased the volume of customs payments and taxes by several times.

In our opinion, it is necessary to attract other diverse enterprises for the successful development of the SEZ. The creation of integrated structures within the framework of the SEZ may become a major factor in national industry modernization.

It is no secret that in most cases the enterprises established in Russia within the SEZ, were interested only in the opportunity to reduce the tax burden.

This is the reason by which we explain the fact that, although a number of preferential conditions, such as preferential export, infrastructure development, etc., was provided to establish production in special zones with a special regime, these competitive advantages remained unclaimed (Andreev, 2016; Bodrunov, 2018; Misakov et al., 2016). Although, of course, the human factor cannot be discarded when such temptations are announced.

But we do not call for an end to the format of special economic zones under consideration due to their inefficiency. Indeed, the world practice of such territory organization has shown the advantages of such projects convincingly for several decades.

It is necessary to return to the beginning of this process and to allow only those enterprises into the zone that, due to their innovativeness, are required to appear as SEZ residents. For this, a special council should be created, consisting of public experts and members. Although this is not a panacea, for an enterprise that met the 
requirements of a special council can may produce the products not corresponding to the application very easily. We believe that in such cases it is necessary to remove such enterprises immediately from the list of residents of the SEZ with all the ensuing circumstances without any warning.

A number of examples can be cited when an enterprise that does not fully comply with the rules of the SEZ nevertheless it received "go-ahead" in the form of an "exception". All this destroys the competitive environment and discredits the very idea of the SEZ.

Because of this situation, 24 billion rubles allocated for the development of thirty-three SEZs have not been disbursed over the past 11 years, and with the total cost of 186 billion rubles, the return in the form of tax revenues amounted to 40 billion rubles only (Grinevich, 2019).

Apparently, this can explain the introduction of curators by the Government of the Russian Federation for 10 lagging, depressed regions. They were selected in the ranking as the regions with the worst positions on the most important estimated indicators, such as the average per capita income for the regional population, the share of the population with the incomes below the subsistence level, the unemployment rate, the investment in fixed assets, etc. Note that the government allocates substantial funds from the federal budget for all these regions annually.

At that, federal ministers act as curators. So, the RF MA D. Patrushev was appointed curator in the depressed republic of Adygea that we mentioned, where the SEZ were not developed.

It is difficult for us to talk about the validity of this approach, since it is impossible to imagine the way, for example, the Ministry of Agriculture of the Russian Federation should and the way he will develop a strategy for the socio-economic development of the Republic of Adygea. It is difficult to imagine how the experts from the Ministry of Agriculture of the Russian Federation will synchronize the work of all various ministries of the republic and determine the priority areas for the development of the territorial economic complex. And this is not the end of the matter - all regional programs developed by the new curators should be protected in the Government of the Russian Federation. 
Obviously, with this approach, the effect for the economy is not obvious if we put it mildly. After all, the main problem of the Russian Federation subjects is an unevenly distributed tax base (without taking into account corruption - this is a separate issue). It is difficult for us to agree that some minister (even a federal one) will be able, in addition to his daily, laborious and voluminous work, to understand in more detail all the problems of a single republic, in all its vicissitudes. In particular, with the same corruption, which is usually "covered" quite often by the same law enforcement agencies, etc.

The new work of 10 ministers for depressed region restoration just begins. But it seems to us that such an institution of supervision is doomed. Here we see another thing - an extraordinary increase of the federal center intervention in the regional economy.

In our opinion, such centralization of socio-economic and budgetary decisions will only reduce the incentives and motivation of the regions for regional economy development and show fake "growth".

\section{Conclusions and Offers}

- Due to the circumstances considered in the article the RF SEZs were not able to provide "accelerated socio-economic development". It seems to us that when the SEZ was opened, a formal approach was allowed and there was no objective control over the compliance of the RF subject territories and the residents with the requirements imposed in such cases.

- In Russia, when the SEZ was opened, the gree-fild principle, well-established in international practice, is ignored. The consequence of this assumption is that when you choose the location of SEZ, all work was reduced to the struggle of individual subjects of the Russian Federation, municipalities, etc. for "their" interests, while the interests of the state were discarded.

- In our opinion, this is natural, because the state strategy for the creation and development of the SEZ was not a systemic, but "mosaic". During its development, certain aspects of the fundamental foundations of strategic management and planning were ignored. 
- In a generalized form, it is advisable to consider the strategic management of the SEZ from two aspects:

- In the form of structural management as a process;

- In the form of a way to ensure desired results.

In this case, the organizational and economic model of SEZ strategic management can be represented in the following aspects:

- in the form of a process organizational and economic model of SEZ strategic management in the regional socio-ecological-economic system;

- in the form of a mechanism for the interaction between the SEZ management company and the authorities of the constituent entity of the Russian Federation and municipalities, with the SEZ residents, investors and other interested partners.

\section{Conflict of Interest}

The authors confirm the absence of a conflict of interest.

\section{References}

Afashagova, S. R., Misakov, V. S., \& Ivanov, A. A. (2014). Some tools to stimulate the innovative development of the business environment in the republics of the NorthCaucasian Federal District. Bulletin of the Kabardino-Balkarian Scientific Center of the Russian Academy of Sciences, 5(61), 75-81.

Aloeva, Z. A., \& Misakov, V. S. (2013). The development of adaptation and anti-crisis measures in terms of increasing competition. Bulletin of the Kabardino-Balkarian Scientific Center of the Russian Academy of Sciences, 6-2 (56), 30-35.

Andreev, V. A. (2016). Identification of organizational and functional models of priority development territories in the Russian Federation. Russian Journal of Entrepreneurship, $17(5), 631-641$.

Baklanov, P. Ya. (2014). The territory of advanced development: concepts, structure, approaches to allocation. Regional Studies, 3, 12-19

Bodrunov, S. D. (2018). The territories of advanced development are the most important condition for the economic growth of Russia. Manager, 1, 2-7.

Bos, H. (1970). Housing. - M.: Progress, - 158 p. 
Enright, M. J. (1993). The Ceographical Scope of Competitive Advantage. Stuck in the Pegim?, $117 \mathrm{p}, 87-102$.

Grinevich, D. (2019). Diagnosis - SEZ. News, May 30, 96(30328).

Krutikov, V. K. (2017). Advanced Development Territories. Kaluga: Publishing house of the ACF "Politon", - 148 p.

Kushbokova, R. Kh., Shamurzaev, Z. S., \& Misakov, V. S. (2009). Some approaches to innovative potential management of an industrial enterprise. TerraEconomicus, 7(4-3), $123-125$.

Misakov, A. V., Molamusov, Z. Kh., \& Misakov, V. S. (2016). Some methods of investment activity modeling at industrial enterprises in terms of uncertainty. Economics and Entrepreneurship, 1-2(66), 606-610.

Myakisheva, E. A. (2015). Methodological support of strategic management for the territory of advanced social and economic development. Abstract: from the thesis by $\mathrm{PhD}$ in Economics. Perm: PSNIU, - $24 \mathrm{p}$.

Perroux, F. (1968). Les investissementsmultinationaux et L'analise des poles de developpement et des poles d integration. Revue Tiers-Monde, 9(34), 239-265. 